UNITED STATES DEPARTMENT OF COMMERCE ELIMINATION OF WASTE SERIES

\title{
RECOMMENDED PRACTICE FOR
} ARRANGEMENT OF BUILDING CODES

\section{REPORT \\ OF}

BUILDING CODE COMMITTEE

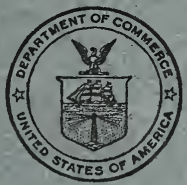

BUREAU OF STANDARDS 
(1)

5

$x=400^{2}$

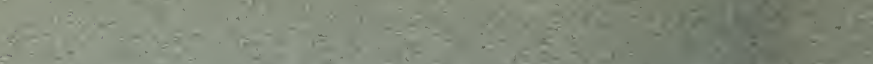

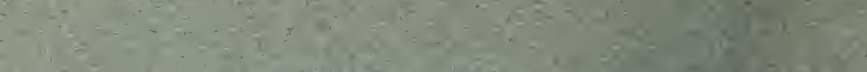

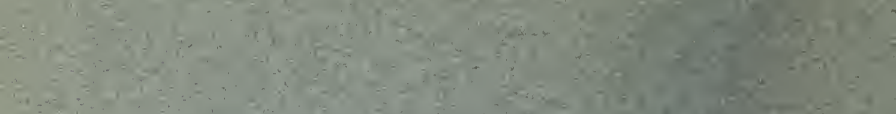

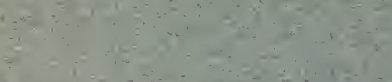
$4-2+2+9$

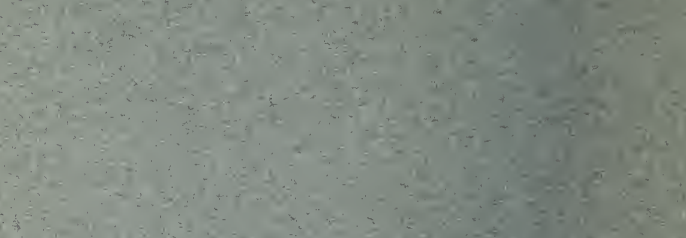

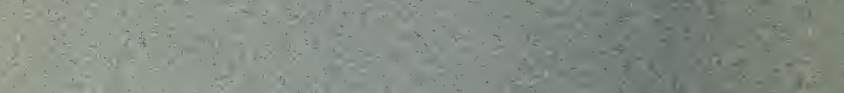

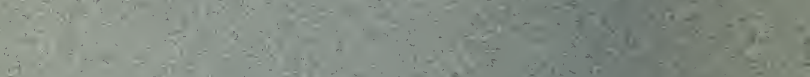

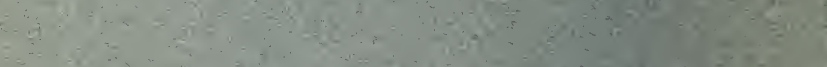

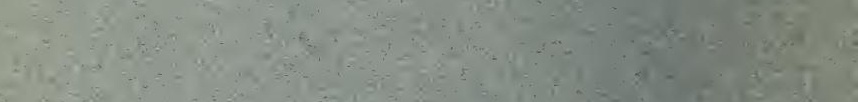

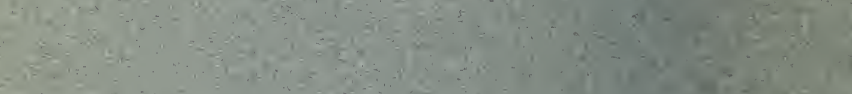

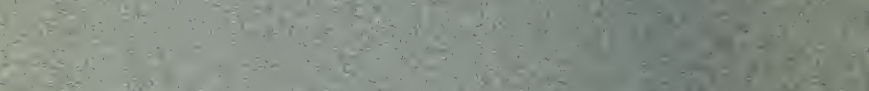

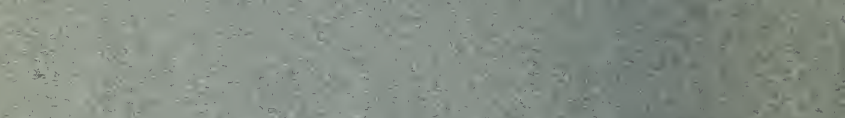

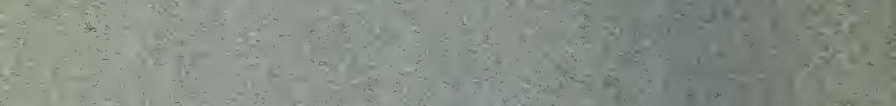

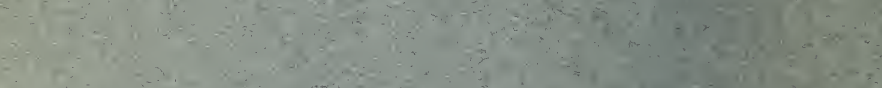

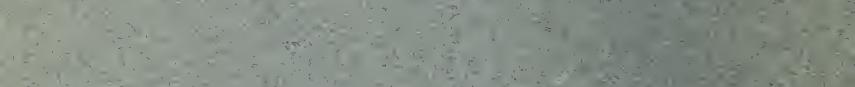

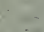

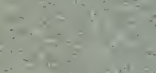

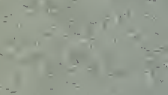

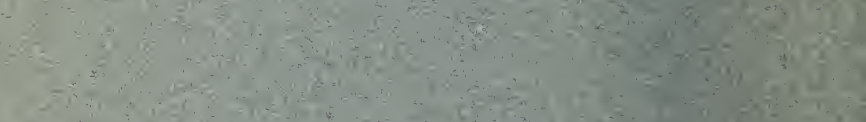

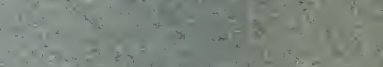

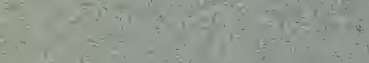

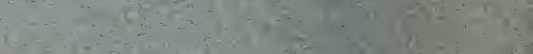

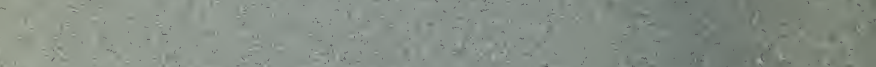

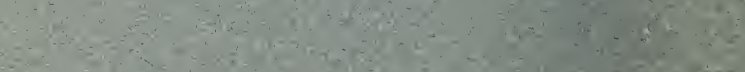
y.

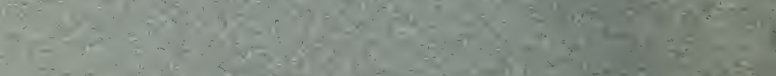

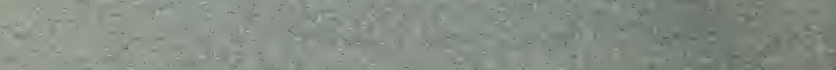

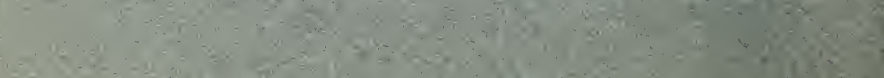


UNITED STATES DEPARTMENT OF COMMERCE HERBERT HOOVER, SECRETARY

ELIMINATION OF WASTE SERIES

\title{
RECOMMENDED PRACTICE FOR ARRANGEMENT OF BUILDING CODES
}

\author{
REPORT OF \\ BUILDING CODE COMMITTEE
}

JULY 15, 1925

\section{Ira H. Woolson, Chairman}

Edwin H. Brown

William $\mathrm{K}$. Hatt

Albert Kahn
Rudolph P. Miller

John A. Newlin

Joseph R. Worcester

Frank P. Cartwright, Technical Secretary

JOHN M. GRIES, Chief

Division of Building and Housing

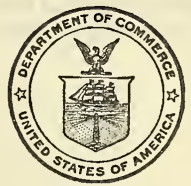

BUREAU OF STANDARDS

PRICE 10 CENTS

Sold only by the Superintendent of Documents, Government Printing Office Washington, D. C. 


\section{MEMBERSHIP OF THE BUILDING CODE COMMITTEE OF THE DEPARTMENT OF COMMERCE}

IrA H. Woolson, Chairman, Consulting Engineer, National Board of Fire Underwriters, New York City; Member, American Society of Mechanical Engineers; American Society for Testing Materials; National Fire Protection Association; American Concrete Institute.

Edwin H. Brown, Architect, Minneapolis, Minn.; Secretary, American Institute of Architects; Member, American Institute of Architects.

William K. Hatr, Professor of Civil Engineering, Purdue University; Member, American Society of Civil Engineers; American Concrete Institute.

Albert $K_{\text {AHN }}$, Architect, Detroit, Mich.; Fellow, American Institute of Architects.

Rudolph P. Mrller, Consulting Engineer, New York City; Past President, Building Officials Conference; Member, American Society of Civil Engineers; American Institute of Consulting Engineers; American Society for Testing Materials; President, National Fire Protection Association.

John A. Newlin, In Charge of Section of Timber Mechanics, Forest Products Laboratory, Forest Service, United States Department of Agriculture, Madison, Wis.; Member, American Society for Testing Materials; American Society of Civil Engineers.

Joseph R. Worcester, Consulting Engineer, Boston, Mass.; Member, American Society of Civil Engineers; American Institute of Consulting Engineers. Frank P. Cartwright, Technical Secretary. 


\section{ON TENTS}

\section{PART I.-INTRODUCTION}

Diversity of existing code arrangement

Reasons for uniform and logical arrangement of building codes........ 2

Purpose of report .

Procedure of committee-_._. 3

Methods of code arrangement...... 3

PART II.-RECOMMENDED OUTLINE FOR BUILDING CODE

List of ehapters.-. 5

Preface-Title and scope_-_. 5

Chapter 1.-Administration._. A

Section 1.1. General provisions

Section 1.2. Enforcement

Chapter 2,-Definitions _._._. 7

Section 2.1. Definitions_._.

Chapter 3.-Classifications _._.

Section 3.1. Classification of buildings by oecupaney

Section 3.2. Classification of buildings by type of construction._-_- $\quad 7$

Chapter 4.-General building restrictions. - G 7

Section 4.1. Restrictions as to location_... 7

Section 4.2. Restrictions as to heights _........ 8

Section 4.3. Restrictions as to floor areas._...... 8

Section 4.4. Restrictions as to location on property

Section 4.5. Construction types for special occupancies.......... 8

Chapter 5.-Zoning _._...... 8

Chapter 6.-Light and ventilation

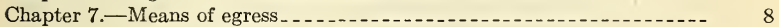

Section 7.1. General egress requirements._.

Section 7.2. Exit doors _._. 8

Section 7.3. Stairways, interior and exterior

Section 7.4. Smoke-proof towers

Section 7.5. Horizontal exits___._._._. 9

Chapter 8.-Materials, loads, and stresses____._. 9

Section 8.1. Quality of materials_....... 9

Section 8.2. Loads_....... 9

Section 8.3. Allowable working stresses _._. 9

Section 8.4. Bearing values of soils_._._. 9

Chapter 9.-Construction _.

Section 9.1. Workmanship_._.

Section 9.2. Excavations__._.

Section 9.3. Foundations...... 10

Section 9.4. Masonry

Section 9.5. Reinforeed concrete.

Section 9.6. Iron and steel . 10

Section 9.7. Wood 
Chapter 10.-Precautions during

Section 10.1. Storage of materials_._. 11

Section 10.2. Protection of public

Section 10.3. Protection of workmen .

Section 10.4. Protection of adjacent property

Section 10.5. Utility and sanitation requirements _._. 11

Chapter 11.-Fire protection

Section 11.1. Fire-resistive materials

Section 11.2. Protection of structural members

Section 11.3. Floors

Section 11.4. Partitions

Section 11.5. Protection of vertical openings__._.

Section 11.6. Protection of wall and partition openings._._._. 12

Section 11.7. Ceilings_._._._._. 12

Section 11.8. Roof structures and roofing

Section 11.9. Fire stopping-_- 12

Chapter 12.-Chimneys and heating appliances__- 12

Chapter 13.--Special occupancy provisions._. 13

Section 13.1. Theaters, assembly halls, and similar buildings _._._. 13

Section 13.2. Factories, mercantile, and similar buildings_._._._. 13

Section 13.3. Places of instruction

Section 13.4. Hotels, apartments, and other similar occupancies_.-_ 13

Chapter 14.-Elevators_-_._- 13

Chapter 15.-Plumbing 13

Section 15.1. Definition of terms_._._. 13

Section 15.2. General regulations _....... 13

Section 15.3. Quality and weights of materials_._. 13

Section 15.4. Joints and connections_._.

Section 15.5. Traps and cleanouts__-_._- 13

Section 15.6. Water supply and distribution 13

Section 15.7. Plumbing fixtures._._. 13

Section 15.8. Ventilation of rooms and fixtures

Section 15.9. Soil, waste, and vent pipes

Section 15.10. House drains and sewers._._. 13

Section 15.11. Storm-water drains._._. 13

Section 15.12. Refrigerator, safe, and special wastes _._._._._._. 13

Section 15.13. Maintenance._._._. 13

Section 15.14. Inspection and tests. 13

Chapter 16.-Heating - -

Chapter 17.-Electrical_...

Chapter 18.--Signs and billboards

Chapter 19.-Fire-extinguishing equipment_._- 14

Appendix . . 14

\section{PART III-APPENDIX}

Paragraph 1. Agencies for drafting or revising codes_.

1. Civic organizations

2. Building officials

3. Local code committees

4. Special consultant

Paragraph 2. The value of a building code.

Paragraph.3. Legal principles_._-

Paragraph 4. Performance standards 
Paragraph 5. Copying of existing codes unwise

Paragraph 6. Brevity in codes desirable

Paragraph 7. Chapters published separately

Paragraph 8. Method of stating requirements_-_-___-_-_-_- 20

Paragraph 9. Additional permits_-_-_._- 21

Paragraph 10. Definitions_-_-_._._. 23

Paragraph 11. Construction classes..-_-_._- 23

Paragraph 12. Standards of workmanship

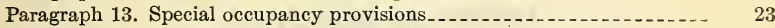

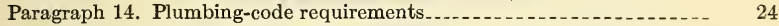

Paragraph 15. Sources of information

1. The Department of Commerce, Washington, D. C._-_-_-_- 24

2. The Forest Products Laboratory, Madison, Wis _._._._-_._-_ 24

3. The National Board of Fire Underwriters, 76 William Street,

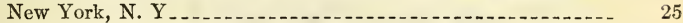

4. Underwriters Laboratories (Inc.), 207 East Ohio Street, Chicago, IIl-_...

5. The American Society of Heating and Ventilating Engineers.---- 25

Paragraph 16. Decimal numbering system

Extract from New York City Building Code............... 26

Paragraph 17. Suggestions as to methods of printing building codes...-. 27 


\section{LETTER OF SUBMITTAL}

\section{Hon. Herbert Hoover,}

Wasmington, D. C., July 15, 1925.

Secretary of Commerce, Washington, D. C.

Dear Str: By direction of the building code committee appointed by you to standardize and simplify existing building code practice, I have the honor to submit herewith the committee's fifth report in fulfillment of its purpose.

This report, entitled "Recommended Practice for Arrangement of Building Codes," if used as the committee hopes it may be, as a standard plan for drafting building ordinances, will effect a decided conservation of time and effort on the part of persons formulating codes and those who must use them. The general adoption of a standard code arrangement would greatly reduce the confusion in existing building ordinances, thus lessening the chances of misunderstanding and making them more convenient for use, particularly by architects and builders operating in different cities.

The report in tentative form has been submitted to public criticism according to the committee's usual procedure. The suggestions thus obtained have been adopted so far as seemed practicable. If the report as now presented meets with your approval, we recommend that it be printed for public distribution.

Yours very truly,

Ira H. Woolson, Chairman Building Code Committee, Department of Commerce. 


\title{
LETTER OF ACCEPTANCE
}

\author{
Department of Commerce, \\ OfFice of the Secretary, \\ Washington, D. C., August 5, 1925.
}

Mr. Ira H. Woolson,

Chairman Building Code Committee,

Department of Commerce.

Mr Dear Mr. Woolson: It is a great pleasure to receive your committee's able report on Recommended Practice for Arrangement of Building Codes. This report will be serviceable in many ways, both through its direct application in promoting uniform arrangement of building codes, and their logical relation to other ordinances, and by clarifying the whole subject of building regulation in the public mind.

In modern communities public regulations are usually required to assure standards of construction necessary for safety and good sanitary conditions, and to protect health, morals, and general welfare. Safety, for example, demands sound construction, prevention of overloading, minimizing fire hazards, and provision of means of egress in case of fire, or other emergency. Health demands control of plumbing. Closely related is the promotion of health, safety, morals, and general welfare by good zoning ordinances, and by provisions regarding light, ventilation, and human occupancies.

This report, by providing a logical topical outline from which to start, will greatly simplify the preparation of codes, insure greater clearness, and leave less chance for the duplications and omissions which are now too common. It will make codes easier for architects, builders, and owners to use, particularly when their arrangement is uniform and follows the system of numbering recommended. Your suggestions should help to simplify procedure in obtaining permits. Uniformity in content will also be promoted, and wider use will be made of the other authoritative reports which the building code committee has produced as a result of its cooperation with building officials, architects, engineers, builders, officers of trade associations, and others throughout the country. 
The outline shows clearly the purposes to be achieved by the various sections. This, with the discussion of workable procedure for framing codes, should be invaluable to local legislative bodies, public spirited organizations and others who wish to frame codes that will protect the public interest and promote economical construction.

Once again you and the other members of the committee have merited the thanks of a large body of professional men, of a great industry, and of the general public.

Yours faithfully,

Herbert Hoover. 


\section{RECOMMENDED PRACTICE FOR ARRANGEMTENT OF BULLDNG CODES}

\section{PART I.-INTRODUCTION}

The building code committee of the Department of Commerce was organized early in 1921, in response to a generally expressed public demand for greater uniformity and economy in building-code requirements. Its first work concerned regulations affecting construction of small dwellings, and a report on that subject was published in January, 1923. Subsequent reports have presented recommended requirements for plumbing installations, for the erection of masonry walls of all types, and for the live loads to be assumed as a basis for building design. ${ }^{1}$

\section{Diversity of Existing Code Arrangement.}

The committee has received numerous complaints that existing building codes leave much to be desired in clarity and convenience of reference. This has been brought out more strongly through investigations of code requirements made in connection with the committee's work. Some codes are very brief, omitting whole chapters of important building regulations entirely, and treating others so inadequately as to leave much doubt of their meaning. Other ordinances are unnecessarily verbose.

The arrangement of subjects and their subdivisions seldom follows the same order except when one code is practically a verbatim copy of another. Sections on administration frequently are scattered throughout the body of the ordinance, leaving the prospective builder uncertain whether he has complied with all the preliminaries. Requirements stated in one chapter are found considerably modified in another, and without a cross reference to protect the user of the ordinance from error. Matters not even distantly related to each other are treated in the same sections. Complementary provisions, on the other hand, are often separated by several pages or chapters. To add to the confusion most codes are inadequately indexed, and some not at all. A brief investigation disclosed codes of 160,45 , 54,56 , and 80 pages, respectively, without any indexes at all, and others with indexes so brief as to afford little assistance to the user. Some codes are indexed by topics, others serially and others by

1 For list of departmental publications on building and building regulation see back cover page. $61437^{\circ}-25 \dagger-2$ 
ehapters. Still others are very elearly indexed and the ease with whieh these last can be used proves the value of elose attention to this detail.

Without doubt the confused arrangement of existing codes is due to three principal eauses: First, beeause they have been amended from time to time as new subjeets for regulation arose without arranging the added material in proper relation to the rest of the ordinanee; seeond, beeause eodes have been eompiled by eopying material from two or more existing eodes without sufficient eare to prevent variation and duplieation of requirements in different parts of the ordinance; and, third, beeause those responsible for printing the ordinanee did not appreeiate the great advantage to users of having the regulations. follow eaeh other in a uniform and logieal relation.

\section{Reasons for Uniform and Logical Arrangement of Building Codes.}

A building code, more than any other type of munieipal enaetment, requires a systematie and logieal arrangement of the subjeet matter. Sueh an ordinanee eontains a large number and variety of regulations, and frequently one eonstruetion item may be eontrolled in several different ways by faetors affeeting its location and use. These eonditions make it extremely diffieult for the builder to be eertain what is required and to be sure that he has eomplied with all the regulations coneerning a strueture. Systematie arrangement lessens these difficulties. There also is an advantage in logieal arrangement in that it makes the justness and fairness of the regulations more apparent to those affeeted and thus faeilitates enforeement of the ordinance. Few persons oppose publie regulation for its own sake, but rather from the idea that the burden falls unevenly on them.

Committees responsible for eode drafting or revision frequently find the subjeet rather appalling in the number and eomplexity of its subdivisions, and mueh time is lost through lack of a definite program of procedure. A logieal arrangement of a new ordinanee. saves time by preventing eontradietory provisions oceurring in different plaees and helps to avoid the omission of neeessary requirements. For arehiteets or builders operating in several eities or States it is particularly desirable that provisions dealing with the same subjeet be found in the same plaee in all eodes. The designer is mueh less likely to overlook matters peeuliar to local praetice if all requirements for eaeh subjeet are stated as nearly as possible together. Under present conditions extensive eorrespondence, and frequently a visit to the building official's offiee in a distant eity, is neeessary to ascertain eompletely the eode requirements. 


\section{Purpose of Report.}

In view of the prevailing lack of order and consistency in buildingcode arrangement, with its resulting disadvantages and the obvious gains to be expected from more systematic treatment, this report has been prepared to serve as a guide for uniformity. It also is intended to answer some of the questions of procedure which confront a city planning to write or revise a building code.

\section{Procedure of Committee.}

Work incidental to preparation of previous reports had assisted considcrably in formulating a viewpoint on codc arrangement. When the preparation of a report on this subject was undertaken, howcver, the views of a number of specialists in this field were solicited, and several meetings of the committee were held, after which a tentative draft of recommendations was submitted for critical review to over 500 architects, engincers, building officials, and others whose interest and wide cxperience qualified them to contribute to the subject.

A broad consensus of opinion on code arrangement and methods of code writing was thus obtained, and the tentative draft was considerably revised. The final report is submitted with the hope that it will promote prompt and efficient action by code-writing bodies and that future building codes will be arranged along the lines suggested in Part II.

\section{Methods of Code Arrangement.}

The methods of code arrangement which are worthy of consideration may be classified almost without exception under two hcadings. The first takes up each major class of occupancy, as, for example, office buildings, tenements, small dwellings, factories, etc., and gives in separate chaptcrs a full statement of code provisions applying to each, even though this involves considerable repetition. Certain general matters, such as allowable working stresses, the quality and testing of materials, administration, etc., are treated in separate chapters without reference to occupancy. The result is practically a complete code for each type of building, which greatly increases the amount of printing, and consequent sizc and cost of the publication.

The second method classifies buildings by type of construction and gives the fundamental structural features of each type. Occupancies also are classified and the gencral construction type necessary for each occupancy class is specified. This is followed by chapters giving the detailed requirements for cach construction type and for other essential features, such as quality of materials, means of egress, etc., from which the rcquirements for each building may be selected. 
Each method has certain inherent advantages, but the committee, after giving careful consideration to their relative merits, with emphasis principally upon convenience of use and economy in printing, decided that the second is the more desirable. A scheme of arrangement based on the second method is here presented. Several arrangements of the principal subdivisions have been proposed, but, all things considered, that recommended in Part II is believed the most desirable. It is not so important that a particular order be adopted as it is that all codes should follow practically the same order, and it is urged, therefore, that the principal topics and subdivisions of all codes follow the order suggested as closely as possible. Variations in minor matters, prompted by local preference, are not objectionable.

The committee has not attempted in Part II to mention every detail which might be treated in a building code. It is believed, however, that the major subdivisions are listed in a logical order which will permit arrangement of details in their proper relation. The outline includes items which in some localities are not considered parts of building codes. These are presented merely for the purposes of those who may wish to treat the subject of building regulation systematically in one ordinance or series of ordinances.

Certain subjects, such as masonry walls, live loads, and plumbing, which have been treated by the committee in previous reports are outlined more fully than others in Part II. This is to make generally available the sequence which after much study has been found desirable in treating these subjects.

An index with numerous cross references is very essential and greatly promotes convenient use of a code. Collecting all the provisions relating to each subject in the appropriate chapters promotes simplification and avoids repetition and the seeking of pertinent requirements among several titles. The numbering of subdivisions by the decimal system facilitates cross reference and permits inserting new sections or amendments without disturbing the numbering. The idea was offered for consideration by those criticizing the tentative report and received quite general commendation.

The committee desires to acknowledge the assistance of the numerous collaborators who have helped in bringing the recommended outline to its present form. It has been impracticable to reply individually to all the suggestions and criticisms received in regard to the tentative draft of recommendations. Some of the more important, however, are discussed in the appendix to the report. 


\section{PART II.-RECOMMENDED OUTLINE FOR BUILDING CODE}

\section{LIST OF CHAPTERS}

Preface.-Title and scope.

Chapter 1. Administration.

2. Definitions.

3. Classifications.

4. General building restrictions.

5. Zoning.

6. Light and ventilation.

7. Means of egress.

8. Materials, loads, and stresses.

9. Construction.

10. Precautions during erection.

11. Fire protection.

12. Chimneys and heating appliances

13. Special occupancy provisions.

14. Elevators.

15. Plumbing.

16. Heating.

17. Electrical.

18. Signs and billboards.

19. Fire-extinguishing equipment.

\section{PREFACE.-TITLE AND SCOPE 2}

The prescribed enactment clause, the title of the ordinance and a description of its scope, as applying to new and old buildings and area of district governed; references to State or other laws affecting building in the same district; to repeal previous or conflicting legislation on subject; to provide method of amendment by ordinance or by ruling or interpretation issued by building official.

\section{CHAPTER 1.-ADMINISTRATION}

To give all general requirements and directions necessary for just and effective enforcement of the regulations, and to protect the public interest, so far as threatened by the erection and alteration of buildings.

2 The title and scope of the ordinance are not given a section number but are an essential part of the ordinance. The code should begin with the enacting clause prescribed by city chartcr or State law. 


\section{Section 1.1. General Provisions.}

1.11. Application for permits.

To provide that construction shall not begin without a permit; to deal with filing of applications and plans, the extent and character of information required, the number of copies to be furnished; to provide for amendments to plans and applications, and other related details; to specify requirements for permits covering temporary structures, signs, billboards, wooden fences, etc.; to give the fees charged for permits.

\subsection{Issue of permits.}

To provide for issue of permits or revocation of same on due cause; to describe the procedure necessary when a permit is refused; the disposition of plans and specifications; the process for issuing temporary permits and the display of permit posters.

\subsection{Certificate of occupancy.}

To deal with the issuance of occupancy permits after a building is completed and approved; the building official's responsibility as to final inspection and approval; the builder's observance of this ruling and the classes of occupancy to which the ruling applies. To provide also for certification of existing buildings.

\subsection{Change of occupancy.}

To require reporting of occupancy changes to building official; to provide for the information necessary to determine safety of structures for new uses or for issue of a new certificate of occupancy.

1.15. Alterations and removals.

To exempt ordinary repairs; to provide for special measures incidental to altering, moving, or demolition of structures.

1.16. Interdepartmental cooperation.

To provide for necessary cooperation between city engineer, health officers, police and building officials, and for other measures, such as the furnishing of information by the building official to the assessment department, the submission of applications to the city zoning authorities, etc. (See Appendix, par. 9.)

1.17. Invalidity of one section not to affect any other.

1.18. Date code becomes effective.

\section{Section 1.2. Enforcement.}

1.21. Powers and duties of building oficial.

To confer necessary authority for enforcement; to describe in a general way the qualifications, duties, and responsibilities of the building official and his subordinates and the rules for conduct of the building official's office unless this is otherwise provided for. (The term "building official" as here used relates to the official charged with enforcement of the code.) 
1.22. Relations between building official and public.

To provide for building official's right of entry and for proper inspection facilities.

\subsection{Approval of materials and construction.}

To provide authority for conducting tests and for accepting tests made by disinterested authorities; to prescribe the procedure for approval of new materials or construction methods not covered in the code.

1.24. Demolition of dangerous structures.

To provide authority for removing or vacating dangerous buildings or for other emergency action.

1.25. Violations and penalties.

To describe course of action when violations are detected, and penalties incident to such violations; to confer the right to institute other appropriate actions to bring about removal of violations.

1.26. Board of appeals.

To describe organization, functions, and authority of board of appeals; method of appeal from building official's decision.

\section{CHAPTER 2.-DEFINITIONS}

\section{Section 2.1. Definitions.}

To define all terms used throughout code which are not definitely and uniformly interpreted by experienced builders. (See Appendix, par. 10.)

\section{CHAPTER 3.-CLASSIFICATIONS}

Section 3.1. Classification of Buildings by Occupancy.

To classify buildings by occupancy according to the nature and amount of combustible materials, the number and distribution of occupants or the purpose of the structure; also to provide for treatment of mixed occupancies.

Section 3.2. Classification of Buildings by Type of Construction.

To describe the types of building construction which by reason of materials used and their manner of incorporation in the structure possess varying degrees of fire resistive capacity. (See Appendix, par. 11.)

\section{CHAPTER 4.-GENERAL BUILDING RESTRICTIONS}

Section 4.1. Restrictions as to Location.

To cover fire limits and restrictions as to erecting or renewing buildings of certain construction types or occupancies within fire. limits or in other special districts. 
Section 4.2. Restrictions as to Heights.

To limit the heights to which different construction types may be erected for different occupancies.

Section 4.3. Restrictions as to Floor Areas.

To limit the maximum undivided floor areas allowed between fire walls or exterior walls in different construction types, both with and without sprinkler protection, as affected by occupancy, height of building, and number of sides on which building is accessible for fire fighting.

Section 4.4. Restrictions as to Location on Property.

To restrict the location of buildings with reference to lot lines.

4.41. Limitations on projections beyond the building line.

Section 4.5. Construction Types for Special Occupancies.

To fix types of construction required for various classes of occupancy.

\section{CHAPTER 5.-ZONING}

To regulate, for the different classes of districts into which the municipality may be divided, the use to which land and structures may be put; the height or number of stories of buildings (see also section 4.2 and chapter 6 ); and the area of the lot to be occupied by buildings. (See Appendix, par. 7.)

\section{CHAPTER 6.-LIGHT AND VENTILATION}

To regulate the arrangement, lighting, both natural and artificial, and ventilation of buildings; to fix the sizes of yards, courts, and other open spaces; to regulate the size of rooms; to provide for the ventilation of all assembly spaces.

\section{CHAPTER 7.-MEANS OF EGRESS}

Section 7.1. General Egress Requirements.

To cover proportioning of exits to floor area or occupancy; number and location of exits.

Section 7.2. Exit Doors.

To fix capacity, minimum width, regulations as to hanging and direction of swing, and limitations of revolving doors; exit signs.

Section 7.3. Stairways, Interior and Exterior.

To determine capacity, location, continuity, landings, construction, materials allowed, and inclosure types for different conditions.

Section 7.4. Smoke-proof Towers.

To determine capacity, when required, construction types, and details of design. 
Section 7.5. Horizontal Exits.

To provide for forms of horizontal exits; through or around walls; over bridges or roofs; capacity, requirement of fire doors, and floor area necessary each side of exit.

\section{CHAPTER 8.-MATERIALS, LOADS, AND STRESSES}

\section{Section 8.1. Quality of Materials.}

\subsection{Grades.}

To describe the grades of materials covered in section 8.3 .

\subsection{Tests.}

To describe specifically methods of testing materials not provided for in the code.

\section{Section 8.2. Loads.}

\subsection{Dead.}

To give the weights to be assumed per unit of construction material as bases for safe design of buildings.

\subsection{Live.}

To prescribe the minimum assumed live loads, other than wind pressures, for which the structural members of buildings are to be designed; concentrated loads; live load reductions.

\subsection{Wind pressures.}

\section{Section 8.3. Allowable Working Stresses.}

To give the unit working stresses of materials employed in building construction; stresses due to wind; secondary stresses.

8.31. Factor of safety.

To fix factors of safety for new building materials or construction methods not covered by given allowable stresses. (See Appendix, par. 4.)

\section{Section 8.4. Bearing Values of Soils.}

To fix the presumptive bearing capacities of soils; to provide for tests when bearing values are in question.

\section{CHAPTER 9.-CONSTRUCTION}

\section{Section 9.1. Workmanship.}

To require good workmanship generally for the essential structural and fire-resistive parts of a building. (See Appendix, par. 12.)

\section{Section 9.2. Excavations.}

To describe the necessary precautions in excavating for a building, as affecting safety of structure or permanence of foundations. (See also sec. 10.4.)

$$
61437^{\circ}-25 \dagger-3
$$




\section{Section 9.3. Foundations.}

9.31. Footings.

To fix extent and proportions of footings and foundations.

9.32. Pile foundations.

9.33. Retaining walls.

9.34. Vaults and areaways.

\section{Section 9.4. Masonry.}

9.41. Solid brick walls.

To include requirements having to do with thickness, height, or structural details of solid brick walls.

9.42. Hollow walls.

To include requirements concerning thickness, height, or structural details of walls of hollow tile, concrete block or tile or hollow walls of brick.

9.43. Walls of plain concrete.

To include requirements concerning thickness, height, or structural details of walls of plain concrete, solid or hollow.

9.44. Stone walls.

To include requirements concerning thickness, height, or structural details of walls of stone.

9.45. Veneered walls.

To include requirements concerning thickness, height, or structural details of veneered walls.

9.46. Faced walls.

To include requirements concerning thickness, height, or structural details of faced walls.

9.47. Party, fire, and fire division walls.

To include requirements concerning thickness, height, or structural details of party, fire, and fire division walls.

9.48. Miscellaneous masonry wall requirements.

To cover additional requirements applying to the several types of masonry walls; anchorage, the lining or increase in height of old walls, corbeling of chimneys and support of cornices.

\section{Section 9.5. Reinforced Concrete.}

To cover quality of materials not included in section 8.1; statement of special factors and formulas controlling design; beam and slab construction, columns and walls, footings, flat slab construction, placing and spacing reinforcement, fire protection for reinforcement.

\section{Section 9.6. Iron and Steel.}

To cover requirements not included under sections 8.1 and 8.3 and having to do with design of iron and structural steel work; the lighter forms of rolled shapes and trusses; necessary details con- 
cerning assembly of columns, girders, beams, and trusses; protection against corrosion.

Section 9.7. Wood.

Requirements not included under sections 8.1 or 8.3 having to do with design of timber framework. (See sec. 4.3 for allowable undivided floor areas.)

9.71. Ordinary.

9.72. Mill or slow burning.

9.73. Semimill.

9.74. Frame.

\section{CHAPTER 10.-PRECAUTIONS DURING BUILDING OPERATIONS}

\section{Section 10.1. Storage of Materials.}

To limit use of public highway for storage of materials or traffic incidental to construction work; temporary storage structures.

Section 10.2. Protection of Public.

To deal with covered walkways, the handling and hoisting of materials, the proper construction of scaffolds over thoroughfares, and other similar details.

Section 10.3. Protection of Workmen.

To include all measures considered necessary to the safety of workmen during construction.

Section 10.4. Protection of Adjacent Property.

To deal with the lateral support of adjacent property during excavation and its protection against other possible damage during construction; to determine the responsibility for such protection, the carrying up of chimneys, the regulation of party walls, the rights of entry of all parties, and other similar matters.

Section 10.5. Utility and Sanitation Requirements.

To govern the temporary use of water, sewers, provisions for toilet facilities, and installation of electricity or gas services for construction purposes.

\section{CHAPTER 11.-FIRE PROTECTION}

Section 11.1. Fire-Resistive Materials.

To describe fire-resistive materials sufficiently to insure suitable performance of such materials in resisting fire; methods of testing; stone, slag, or cinder concrete; building blocks and tiles, plaster, wallboard, etc. 
Section 11.2. Protection of Structural Members.

To give the necessary thickness and details of protection for structural members, with reference to the material of the member and the covering material, based upon the probable duration and temperature of fires in buildings.

Section 11.3. Floors.

To specify the fire resistance periods of floors for different occupancies; to describe typical constructions meeting those requirements.

Section 11.4. Partitions.

To specify the fire resistance periods of partitions for different occupancies and locations; to prescribe minimum construction requirements.

Section 11.5. Protection of Vertical Openings.

To regulate the fire resistance of inclosures for elevators, stairways, dumb-waiters, ducts, and other openings between one story or part of a building and another.

Section 11.6. Protection of Wall and Partition Openings.

To regulate the location and size of openings in exterior walls, fire and fire division walls and partitions, and the protection of such openings by doors, shutters, and windows.

\section{Section 11.7. Ceilings.}

To regulate construction of ceilings for fire resistive purposes and to insure sufficient strength and durability; hung ceilings; cellar ceilings.

\section{Section 11.8. Roof Structures and Roofing.}

To regulate the materials and installation of fire-resistive roofing; the location, height, extent, and fireproofing of roof structures.

\section{Section 11.9. Fire Stopping.}

To provide fire-resistive barriers interrupting concealed spaces in buildings at frequent intervals, to prevent spread of fire from one part of the structure to another.

\section{CHAPTER 12.-CHIMNEYS AND HEATING APPLIANCES}

To give directions for construction of masonry chimneys for various services; sizes; protection from woodwork; fireplace construction; special construction for metal smokestacks or flues for steam boilers or other furnaces; details of construction and protection for heating appliances; high and low pressure boilers, furnaces, stoves, and ranges; location and protection of smoke pipes, steam pipes, warm-air ducts and vent flues; construction of dry rooms. To regulate gas and fuel-oil heating appliances. 


\section{CHAPTER 13.-SPECIAL OCCUPANCY PROVISIONS}

Section 13.1. Theaters, Assembly Halls, and Similar Buildings.

To cover requirements relating to the special risks to be found in assembly places, such as the requirement for a proscenium curtain, of exit lights, of stage ventilators, arrangement of seats, etc. (See ch. 7 for means of egress.)

Section 13.2. Factories, Mercantile, and Similar Buildings.

To provide for the special risks existing in certain occupancies under these classifications, and not otherwise covered.

Section 13.3. Places of Instruction.

To provide for the special risks existing in schools, college buildings, and other places of instruction not otherwise covered.

Section 13.4. Hotels, Apartments, and Other Similar Occupancies.

To provide for the special risks existing in certain cases in these types of buildings, not otherwise covered. (See also Appendix, par. 13.)

\section{CHAPTER 14.-ELEVATORS}

To regulate the construction and equipment of elevators and escalators; to provide for proper maintenance and periodic inspection.

\section{CHAPTER 15.-PLUMBING}

To regulate the installation of drainage, water supply, and gas; to determine the number of fixtures required in proportion to the occupancy. (See Appendix, par. 14.)

Section 15.1. Definition of Terms.

Section 15.2. General Regulations.

Section 15.3. Quality and Weights of Materials.

Section 15.4. Joints and Connections.

Section 15.5. Traps and Cleanouts.

Section 15.6. Water Supply and Distribution.

Section 15.7. Plumbing Fixtures.

Section 15.8. Ventilation of Rooms and Fixtures.

Section 15.9. Soil, Waste, and Vent Pipes.

Section 15.10. House Drains and Sewers.

Section 15.11. Storm Water Drains.

Section 15.12. Refrigerator, Safe, and Special Wastes.

Section 15.13. Maintenance.

Section 15.14. Inspection and Tests. 


\section{CHAPTER 16.-HEATING}

To provide for safe installation, maintenance, and operation of heating equipment. (See Appendix, par. 15-5.)

\section{CHAPTER 17.-ELECTRICAL}

To regulate the safe installation of electrical equipment.

\section{CHAPTER 18.-SIGNS AND BILLBOARDS}

To provide for allowable dimensions, locations, and types.

\section{CHAPTER 19.-FIRE-EXTINGUISHING EQUIPMENT}

To prescribe when and to what extent sprinklers, standpipes, or other fire-extinguishing equipment shall be installed; design and details of such equipment.

\section{APPENDIX}

To give briefly the reasons for certain requirements thought worthy of explanation; to supply information useful to the building official and the builder in interpreting requirements. 


\section{PART III.-APPENDIX}

The building code committee has received from local authorities and private consultants many inquiries and requests which seem to indicate widespread misunderstanding as to what a building code should be; how a code committee or consultant should go about its preparation or revision; and what sources of dependable information are available. Misconception of the police power function and in some cases of the practical limitations of public building inspection causes variations in the requirements of different codes. There is a wide variety, moreover, in the arrangement and indexing of codes; also in the wording of requirements and in other matters which may not seriously impair the effectiveness of such ordinances, but which are prejudicial to their clarity and convenience.

The more troublesome difficulties involved in code drafting are discussed in the following pages and suggestions given for avoiding or overcoming them.

\section{Par. 1. Agencies for Drafting or Revising Codes.}

Building ordinances may originate or be revised by several different methods or agencies.

1. Civic Organizations. - Codes may be drafted or amended by independent civic bodies, such as chambers of commerce or citizens' associations, or by organized effort of some group affected directly by code requirements, the suggestions being adopted by city legislative bodies. This procedure does not as a rule accomplish the best results unless the persons selected for the task are specially qualified. Recommendations thus prepared are liable to overemphasize subjects in which such groups are interested, and the resulting ordinance is not well balanced. On the other hand, civic or commercial organizations can perform a useful function by calling attention to the need of code drafting or revision and by forcing initiation of the work.

Professional and trade organizations have much that is valuable to contribute, but no one group will usually have the time and energy to complete such a large undertaking. There is also the danger that suggestions from any one source or group will not be broadly enough considered.

2. Butlding Offictals.-Building codes often are drafted or revised by building officials, subject to approval by municipal legislative authorities. Some excellent codes have been prepared in this manner where the building official happened to be particularly 
well qualified for such service. Generally, however, a building official alone should not be held responsible for the preparation of the ordinance. There is need for more than one viewpoint on the problem, and the building official, moreover, is often too busy to give such work the time and attention it requires. He is in an excellent position to criticize such legislation from the practical standpoint of enforcement, and can render invaluable cooperative service with a properly selected committee.

The building officials in many cities are empowered to interpret or add to code requirements by rulings, which, after due notice and public hearings, assume the force of law. Such a procedure is necessary and desirable. A code, no matter how carefully prepared, will need further interpretation. Such interpretations are better published, for otherwise they remain unknown except to local designers, and their correctness or justice is not thoroughly subject to public and professional scrutiny.

For reasons given heretofore interpretation or change by special ruling may not be a desirable way to accomplish a general revision. On the other hand, as a means of securing those adjustments and amendments which progress renders necessary, it has its advantages. The effects of innovations are felt first in the office of the building official, and he is in an excellent position to determine their desirability or effectiveness under the general requirements laid down by the code. When such rulings are subject to approval by a properly constituted board of appeals, the danger of injustice arising from such procedure is a minimum. Until recently this method of code interpretation was in force in New York City, the code of which states that-

The superintendent of buildings shall have power to adopt such rules with respect to the materials and mode of construction consistent with the provisions of this chapter as may be necessary to secure the intent and purposes of this chapter and a proper enforcement of its provisions. For any provisions of this chapter referring to the rules for requiring approval of materials or modes of constrvetion, such superintendent shall adopt, when this section becomes effective or as the necessity may arise, such rules as are required or will establish the conditions of approval. So far as practicable such rules shall be uniform in all the boroughs.

A similar provision is in force in Boston, and is utilized by the commissioner of buildings of that city to keep the code up to date.

The Department of Commerce building code committee advocates publication of an appendix with all codes, which will provide in part for such interpretation and aid in supplying the data upon which changes should be based. (See Appendix, par. 17.)

3. Local Code Commitees.-When the drafting or extensive revision of a building code becomes necessary and it is desired to avoid the expense of a specialist by utilizing the knowledge and experience 
of the building official and of local technical and industrial groups, this is most successfully accomplished by organizing a committee representative of all groups affected. It is, of course, necessary that these men be experienced in their particular lines, and that they have the confidence of their respective groups. They should be selccted not alone for their technical ability but also for their capacity to work together effectively in committee procedure. Sometimes outstanding ability may be sacrificed to advantage in order to get men who can see both sides of a question.

The membership should, if possible, be selected from men having some years of experience in architecture, engineering (structural, sanitary, or fire prevention), or may include any specialist in public utilities, foundation work, or building erection who may be available. The chief building official should always be a member. The chief of fire department is also a good man to have on such a committee. Sometimes a well-qualified mason or carpenter can be utilized to advantage. Legal talent can be included, if desired, but usually such assistance is not necessary except to review the finished ordinance to ascertain if it is in binding legal form.

The size of such a committee must depend upon circumstances, but usually five members make a satisfactory working body. A large committee is liable to become unwieldy, though it may sometimes. function effectively through subcommittees to which specific parts of the work are submitted for preliminary investigation and wording.

The members qualifying for such service will be busy men and seldom able to give more than a small part of their time to the work. It will usually be necessary, therefore, to employ a secretary capable of carrying on, under direction, the clerical and research work necessary to put the code provisions in shape for discussion by the committee.

In drafting a local building ordinance, recognition must always be given to any existing State building code or special building laws, and assurance made that the local requirements are at least as strict as the State laws. It is permissible to make local laws more restrictive than State laws, and frequently desirable to do so, for the latter are usually minimum requirements applicable to all municipalities within the State and do not take into account local fire or other hazards which may exist.

4. Special Consultant.-It is best, though not always possible, to secure the scrvices of an architect or engineer experienced in this type of work to write a building code. The services of a specialist are usually expensive as to first cost, but, as in many other fields of endeavor, they will prove well worth while in the cnd.

Unless a building code is drafted with extreme care concerning the correctness of its numerous requirements and their relation to 
each other, obsolete provisions are apt to creep in, also unexpected applications develop which are objectionable and expensive. There is, furthermore, an essential difference between a building specification and a building code, based on the police power, which those who draft building codes frequently fail to appreciate. Codes written by competent architects and engineers often take the form of specifications for good practice instead of stating minimum safe limits. Even definitions frequently are written as specifications. In such cases the result is a code which, because of its numerous and detailed requirements, is only partly enforceable, and which is in effect a law applying to the conscientious, but little heeded by those who need regulation most. This pitfall the specialist is more apt to avoid, with greater resultant economy and freedom of structural design. His practice keeps him constantly in touch with the great mass of investigational work being done by laboratories and professional groups and enables him to utilize the latest discoveries in each field. Such a specialist should always work in conjunction with a local advisory committee, and their joint recommendations should be freely submitted to those interested and should be discussed at public hearings before enactment by the local legislative body.

\section{Par. 2. The Value of a Building Code.}

Even when the need of a modern code is recognized it is often difficult to obtain the necessary funds for its preparation because the benefits which accrue to a community, although tangible, are peculiarly difficult of estimation in direct financial terms.

The great advantage resulting from the adoption of such an ordinance is the general betterment in character of buildings, which in turn improves the city's appearance, benefits health conditions, and diminishes the fire hazard. A proper building code, well enforced over a period long enough to influence the character of construction, reduces the probability of fire spread in individual buildings, and lessens the conflagration hazard. Insurance underwriters, in grading a city according to its fire hazard, as a foundation for establishing a base rate, give credit for adequate building laws and good construction to an extent varying from 15 to 25 per cent of the total number of points employed in the grading.

In addition to this pecuniary advantage to the citizens as a whole, there are usually substantial reductions in premiums on insurance policies covering individual buildings, resulting from the improved construction required by ordinance. The total of such reductions aggregates a considerable financial sum.

\section{Par. 3. Legal Principles.}

Code requirements depend on what is known as the "police power" for enforcement. The police power is that inherent power of govern- 
ment which protects the people against harmful acts of individuals, so far as matters of safety, health, morals, or the like are concerned; and unless a code requirement can be shown to be necessary for such protection, it will not be supported by the courts. The limits of the police power have never been defined lest its flexibility be lost, but, in general, are gradually being extended. It has at times received very broad interpretation, but the usual result when a border-line case is brought into court is to defeat the requirement and to undermine the authority of the building official. Authority to exercise the police power is delegated by the State authorities to cities and a police power regulation enacted by the State legislature will, in general, outweigh a conflicting provision enacted by local authorities.

It is frequently argued that some regulations, based solely upon the idea of assuring good building practice, are justifiable, even if not within the strict interpretation of the police power, because they confer an economic benefit upon the public. This reasoning is commendable in so far as the public will indorse such regulation, and it frequently does so to considerable extent. It must be recognized, however, that such a principle might be applied to other commodities besides buildings.

\section{Par. 4. Performance Standards.}

Wherever possible, requirements should be stated in terms of performance, based upon test results or service conditions, rather than in dimensions, detailed methods, or specific materials. Otherwise new materials, or new assemblies of common materials, which would meet construction demands satisfactorily and economically, might be restricted from use, thus obstructing progress in the industry. It is desirable that opportunity exist for establishing the merits of new or untried forms of construction. Compliance may be established by tests made under the building official's supervision, or by presenting evidence that the prescribed standards of performance have been met elsewhere under competent disinterested control.

\section{Par. 5. Copying of Existing Codes Unwise.}

Sections or articles most emphatically should not be copied verbatim from other codes without careful study of their fitness; and particularly to determine if they conform to standards of uniformity recommended by the Department of Commerce. Many of the defects of existing codes result from this practice. The code from which sections are "lifted" may be an excellent one, but if the borrowing is not done with great care the result will be a disorganized accumulation of requirements, inconsistent with each other, and out of harmony with recent developments. 
The same careful scrutiny should be given a code in process of revision. Conflicting requirements or those which no longer apply should be omitted. Amendments are apt to have wider ramifications than is at first apparent.

\section{Par. 6. Brevity in Codes Desirable.}

Careful study of building codes in practice leads to the conclusion that they should be brief, including so far as practicable only fundamental principles, and that the administrative authorities should be empowered to interpret or extend the application of these principles when necessary by published rulings; these rulings being subject to review by public hearings or other orderly procedure. (See Appendix, pars. 1-1 and 17.)

Both the building official's rulings and revisions of the code proper should be given thorough publicity and should be carefully referenced to the latest published edition as to sections changed, omitted, or added.

\section{Par. 7. Chapters Published Separately.}

Because of the bulky nature of the maps required, or because zoning ordinances are enacted or enforced under other auspices it will frequently be undesirable to print them in the same volume with building laws. When they are included in the code they should be inserted at the point indicated by chapter 5 . Before the designer proceeds to prepare plans for a building the owner must determine whether a building of the type proposed will be allowed on his lot.

It will also be desirable in many cases to separate the electrical and plumbing chapters from the rest of the building code. Their provisions apply to a different group of contractors and tradesmen, and they frequently are enforced by different inspectors.

If the zoning ordinance or other chapters are not given in the code, reference to them should be made at the proper points so that their provisions may not be overlooked by builders.

\section{Par. 8. Method of Stating Requirements.}

Building code requirements frequently are stated in the form of directions that such and such things must be done. This form is open to the construction that all practices or materials not specifically mentioned are, therefore, forbidden, and in fact such requirements frequently are thus understood by builders and building officials.

It is recommended that whenever possible requirements take the form of prohibitions forbidding the dangerous practices it is desired to prevent, rather than directions for the methods or materials deemed satisfactory.

The minor subdivisions of a code section preferably should conform to a regular sequence. For example, the general rule applying 
in a given set of conditions should be followed first by those exceptions in which the requirements of the rule are increased; second by those in which requirements are lessened; and lastly, by the exceptions to which the rule does not apply.

Such a sequence, consistently followed, makes a code easier to read and avoids misunderstandings.

\section{Par. 9. Additional Permits.}

An applicant, who for the first time secures a permit to erect or alter a building, is almost sure to be disappointed if he assumes that the document he has received from the building official gives him authority to proceed at once with the contemplated operation. He will discover that it is generally necessary to secure one or more additional permits to do some of the things essential to the prosecution of the work. In somc cases the builder's permit will not be issued until certain of these extra permits have been obtained. This is generally the case when the payment of fees or the filing of bonds is involved. One correspondent, in comments submitted to the building-code committee, states that "In one of the largest Pacific Coast cities it is necessary to secure from 17 to 22 separate permits and certificates in order to erect a 'flat' building designed to accommodate three or four families."

Among the separate permits most frequently required is that for the storage of building materials in the street during the building operation. It may or may not include permission to construct the sidewalk shed or covering and other safeguards that are now quite gcnerally prescribed for the protection of passers-by. Sometimes it does not include the right to cross the sidewalk with trucks for the removal of excavated earth or the delivery of material on the lot. Such privileges, whether joint or separate, are usually extended by the bureau or other body having control over strcets and highways. They are, as a rule, given subject to the filing of a bond or the payment of a fee. The same body also exercises partial if not complete control over permits for the opening of strcets to make water or sewer connections. The connections themselves, howcver, can not be made until written approvals, also generally involving fees, are obtained from the water department on the one hand and the sewer department on the other. The connections just referred to bcing for the permanent service of the building, do not include the temporary connections, especially for the use of water, during the building operation, for which the contractor must arrange independently. In many cities the service of the city engincer's office for the fixing of the street lines and grades is made a precedent condition to the starting of the work. In some cascs special permission to excavate a lot is necessary. Temporary electric light and power scrvice also requires authorization. 
The matters just mentioned are such as arise in connection with the prosecution of the building operation itself. There are a numbcr of other subjects that are closely related to the plan itself, which are conditional on approval outside of the building official's office. Frequently the provision for ventilation must have the approval of a housing department or of the health authoritics; the location, general outlines, and use of the building must be reviewed by a zoning board or some adjunct of the city engineer's office; the plumbing system requires approval by the officer administering sanitary regulations; the elevator installation is passed on by the elevator inspector; fire appliances must have the sanction of the fire department; the exit arrangements must meet the judgment of a safety board; space to be utilized for vaults under sidewalks must have the approval of the highway bureau; and, where such are allowed, street encroachments, such as steps, bay windows, etc., must receive special action by some official or by the city council.

The proposed occupancy of buildings, when somewhat out of the ordinary, frequently must be reviewed and approved by agencies in addition to the building official. Thus, plans for buildings to be used as slaughtcrhouses may not be approved without the consent of the health officer; motor-vehicle service and filling stations in certain towns require the sanction of the police authorities; theaters must first meet with the approval of a license commissioner; hospitals require certificates of a welfare department; and school plans, in addition to city regulation, must be approved by State educational authorities.

The systcm of multiple permits as indicated above is an unfortunate development in municipal administration. As the commentator previously referred to points out, the situation probably "has not been brought about intentionally by the city officials. It is merely a situation developed ovcr a period of years, because no particular agency made it a business to recommend a program to coordinate effort and eliminate red tape." The system is without doubt an inefficient and uneconomic one, and costly to taxpayers as well as to those more directly affected, namely, owners, architects, and builders. Some of the duplication in inspection of plans may be unavoidable and, perhaps, even desirable. Most of it, however, can be eliminated. The building official's office can be made fully competent to administer all the provisions of laws or ordinances applying to the designing, construction, use, operation, and maintenance of buildings. If, as a matter of expediency, or for any other reason, it should seem necessary or desirable, in any particular municipality, to retain approval of certain features of building plans, or the issuance of special permits, in an official or body other than the building official, it would still be possible, in the interest of economy of time 
as well as money, to have these required special approvals and extra permits secured through the permit clerk of the building department, so that an applicant for a building permit need file his application and pay the prescribed fees at only one time and place. The papers that the applicant fills out can be made to embody all the several forms necessary for complete record and provide for indorsements of all the officials who review the plans.

\section{Par. 10. Definitions.}

It is contemplated that general terms which appear throughout the code, and which are held to need definition, will be defined in the beginning under section 2.1. Definitions of terms used only in one chapter or section should be given as near the point of use as possible.

\section{Par. 11. Construction Classes.}

There is a tendency in some parts of the country to define and provide for the use of semifire-resistive construction types, falling between completely fire resistive and ordinary construction in its fire-resisting capacity. For special occupancies which require economical construction and in localities readily accessible to fire apparatus it may be desirable to provide for such a classification.

\section{Par. 12. Standards of Workmanship.}

Building codes can not legally regulate workmanship except in so far as it relates to the strength or stability of a structure or the necessary fire resistance of its parts. A section should be included, however, which states in general terms that good workmanship is required. This enables the building official to supervise minor matters effectively even though not specifically included in the code. Ample directions for good workmanship, which may be utilized under such a general statement, are available in the publications of the national architectural and engineering societies and of the leading building industry associations.

\section{Par. 13. Special Occupancy Provisions.}

It is the intention in Part II, chapter 13, to provide a place for the more or less unrelated and miscellaneous requirements applying specially to one or more occupancies and not coming under any other headings in the proposed outline. It is believed that these should be given under heading of the particular occupancies affected, and arranged in the general order of the classes given. Occupancies not coming under these classes may be covered by one or more additional section numbers.

Under this chapter heading, for example, might come special requirements for garages, gasoline filling stations, ice houses, grain elevators, storage for explosives, reviewing stands, airship hangars, $\mathrm{X}$-ray film storage in hospitals, motion-picture machine booths, etc. 


\section{Par. 14. Plumbing-Code Requirements.}

It is recommended that the further subdivisions of plumbing-code requirements follow the arrangement of those presented in the report on Recommended Minimum Requirements for Plumbing in Dwellings and Similar Buildings, prepared by a committee of eminent sanitary engineers and published by this department.

An additional source of information on the content of such regulations is available in the report on "Tests on the Hydraulies and Pneumatics of House Plumbing," by Prof. H. E. Babbitt, of the University of Illinois Engineering Experiment Station.

\section{Par. 15. Sources of Information.}

One of the first steps in preparing a building code is to assemble the best and latest publications on each division of the subject for reference. These should include all available reports of investigations on properties of structural materials. Such investigations are constantly being made and valuable new data are accumulated each year. Publications bearing on code work proceed from several sources, of which the following are most important.

1. The Department of Commerce, Washington, D. C.-For many years the Bureau of Standards, which is a part of the department, has been conducting very valuable experiments on the strength and fire resistance of building materials and construction. These investigations are reported in a series of technologic papers issued by the bureau, and are available for public use. ${ }^{3}$ So far as they concern building regulation, a few of these have been partly summarized in the reports thus far prepared by this committee and published by the department. ${ }^{4}$ Other reports by the building code committee are in process of preparation, and will be available later. These reports are compiled with great care and with reference to sources of information and opinion which it is practically impossible for private or municipal agencies to command. They represent the consensus of opinion of a very large number of qualified experts who served in an advisory capacity to the committee. They are recommended for city or State adoption as nearly as possible without modification, with the object of eliminating wasteful and inconsistent requirements and stimulating uniformity.

2. Tha Forest Products Laboratory, Madison, Wis.-This is an agency established by the United States Department of Agriculture, to investigate the strength and other properties of all varieties of woods, particularly in form of timber and lumber. Its findings are based on a wealth of tests and observations and are recommended as the best information upon the subject.

${ }^{3}$ See Burean of Standards Circular No. 24, which contains a complete descriptive list of these pamphlets.

$\triangle$ See back cover page for titles of these reports. 
3. The National Board of Fire Underwriters, 76 William Street, New York, N. Y.-For a number of years this board has distributed recommended model building codes and other literature helpful to those drafting building ordinances. These publications. give special attention to fire prevention and fire protection matters. They are excellent sources of information. The organization has an extended experience in code drafting and is prepared to review proposed new building ordinances and to make suggestions for their improvement.

4. Underwrtters Laboratories (INc.), 207 East OHIo Street, CHICAGo, Ill.- This is an institution established by the National Board of Fire Underwriters for determining the fire resistance of materials, equipment, and construction, and creating standards for same. A factory inspection and label service are maintained which aim to keep commercial supplies of materials and equipment up to standard, thus promoting successful service.

Though an organization primarily devoted to obtaining information for underwriting purposes and having no governmental authority, and while charges are made for the work, the laboratories have always maintained a high standard of professional responsibility, relating their standards as closely as possible to actual practice requirements and conducting their tests with due regard for the interests both of producers and users of tested products. The laboratories' findings and publications are a dependable source of information as to the test performance of materials and constructions and are, therefore, reliable for reference or use in drafting buildingcode requirements.

5. The American Society of Heating and Ventulating EngiNEERs.-This society maintains a research laboratory with a director in charge and a corps of assistants who are engaged in solution of fundamental problems connected with the science of heating and ventilation. Publications reporting on this and other aspects of the society's activities are understood to be available.

6. The National Electrical Code for regulation of electrical work has been approved as an American standard by the American Engineering Standards Committee and is recommended for adoption by all cities and States not already using it.

7. There are a number of university laboratories which conduct elaborate physical researches on materials and construction. The reports of these investigations are valuable and reliable sources of information.

8. The papers and proceedings of national and, in some cases, sectional societies of architects and engineers contain much of value to the code writer which can not be found elsewhere. Among the most notable contributors to such literature are the American 
Society of Civil Engineers, American Society of Mechanical Engineers, American Society for Testing Materials, National Fire Protection Association, American Concrete Institute, and the Building Officials' Conference.

9. A number of industrial organizations publish information bearing on the use of their products, which is often useful for reference in code work. Recommendations of these groups are usually quite sound, but are apt to partake too much of the nature of specifications.

\section{Par. 16. Decimal Numbering System.}

So far as known the numbering of subdivisions of a building code by a decimal system to indicate their succession and relative importance in the scheme of arrangement has been attempted for the first time in this report. Its suggestion in the tentative draft occasioned some favorable and some unfavorable comment. The committee believes that numbering of subdivisions in this fashion will facilitate cross reference at all times and will furthermore make it possible to add to or revise sections of the code at the right points without affecting the general scheme of numbering; a difficult matter with the customary serial numbering.

If the decimal system of numbering here recommended is not utilized it is suggested that code sections be numbered serially throughout, it being much less confusing than to number the sections in each chapter separately. The principal defect of this system is that the insertion of amendments or new material upsets the numbering. Following is given a page from the code of New York City, illustrative of the alternative practice here suggested.

\section{EXTRACT FROM NEW YORK CITY BUILDING CODE}

\section{ARTICLE 14}

[In some codes designated as chapter or title]

\section{Wood Construction}

Section 280. Wood beams and girders.

281. Wood columns and posts.

282. Bolting.

283. Stud partitions.

284. Fire stops.

280. Section 280. Wood beams and girders.

1. WIDTH of BEAMs.-No wood floor or roof beam used in any building hereafter erected within the fire limits shall be less than 3 inches thick.

2. Supronts.-Every wood beam, except header and tail beams, shall have bearings of at least 4 inches. The ends of all such beams, where they rest on brick walls, shall be cut to a bevel of 3 inches in their depth.

(Balance of wording omitted) 
3. Bridging.-All wood floor and roof beams shall be properly braced with cross bridging. The distance between bridging or between bridging and bearing shall not exceed eight feet.

4. Anchoring-(a) Beams in walls.-Each tier of beams shall be anchored to the walls at intervals of not more than 6 feet with approved steel or wrought iron anchors.

(b) Beams on girders.-(Wording omitted.)

(c) Girders.-(Wording omitted.)

(d) Anchor strips.-(Wording omitted.)

5. Fire Preventron-(a) Trimming around flues.-All wood beams shall be trimmed away from all flues and chimneys.

(Balance of wording omitted)

(b) Separation in walls.-(Wording omitted.)

281. Section 281. Wood columns and posts.

All wood columns and posts shall be squared at the ends perpendicular to their axis, and cap and base plates shall be provided.

(Balance of wording omitted)

282. Section 282. Bolting

$\left.\begin{array}{l}\text { 283. Section 283. Stud partitions } \\ \text { 284. Section 284. Fire stops }\end{array}\right\}$ Wording omitted.

Par. 17. Suggestions as to Methods of Printing Building Codes.

Because of the high cost of printing, small or moderate sized cities are frequently deterred from adopting a code sufficiently comprehensive to regulate properly all classes of building construction and accessory matters relating thereto.

City charters or other municipal laws often require that such ordinances shall be printed in full two or three times in one or more newspapers before presentation to city authorities for adoption. Such publicity is expensive and usually the type employed is not suitable for final printing of the ordinance, consequently a double set-up is necessary. To reduce the burden of expense some cities distribute advertising matter throughout the code, but the objection to this practice is self-evident.

In cities where the financing of printing is of such importance as to operate against the adoption of a suitable comprehensive ordinance, attention is invited to the following suggestions:

It is recognized that nearly all building codes contain material that need not be considered as part of the building law. It would be a simple procedure to print all such matter separately with pertinent information and advice to the public as an appendix or rules of practice or under other suitable title. This would avoid the expense of preliminary printing in the public press. Care should be exercised, however, that essentials are not omitted from the code proper. 
A building code recently issued by the city of Elmira, N. Y., is an excellent example of the procedure above suggested, irrespective of the merits or demerits of the provisions covered in the ordinance. The code proper consists of 51 pages and it is followed by 70 pages of what is termed "Book of Practice," all printed under one cover. It is questionable whether some of the subjects treated in this particular "Book of Practice" might not properly belong in the code itself, and additional material might be included that would be helpful information. However, the decision concerning such matters would in each case rest with the authorities drafting the ordinance.

The city of Flint, Mich., prints a small illustrated "Appendix" to its building code as a separate pamphlet. It contains considerable general information concerning recommended building practice, the method for securing permits, and various data, but does not contain departmental regulations. A few other cities publish appendixes of varying types in their building codes.

The new building code of Portland, Oreg., is published in loose-leaf form, the idea being that as subsequent additions or amendments are adopted, such changes can be printed on separate leaves and inserted in the book, thus keeping it up to date without incurring the expense of a full reprint. The plan is reported to have proven satisfactory in this city. Loose-leaf binding would seem to be quite convenient for an appendix or book of practice where frequent changes might be expected.

Before changes in departmental rules are made or new regulations added, ample public notice should be given and an opportunity for a public hearing afforded. The method for accomplishing this should be established by the code. One plan which has been employed requires that when the building official desires to correct new rules or modify existing ones, he shall first cause such proposals to be published in one or more newspapers at least one day for a determined number of successive weeks, and that notice be given for a public hearing. During the period of such publication the notice shall also be posted on the bulletin board in the public office of the building official. After such publication and public hearing, the proposed changes in the rules, subject to such amendments as may result from the hearing, shall automatically become operative and have the same force and effect as rules already in force.

The size of the publication is also a matter for serious thought. At present, out of several hundred existing building codes, it is difficult to find two of the same size. They vary from thin papercovered, vest-pocket booklets to heavy legal bound, royal octavo volumes of over 1,000 pages. In the latter cases the books are usually a code of ordinances in which the building code is one of many, and not available for public use except at considerable expense. 
This is a practice which should be discouraged. The building code should be a separate publication easily obtainable at small cost. The better building laws are known the better building construction will become. Knowledge of the law will lessen misunderstandings between builders and the building department and assist in reducing expense.

The best size for a building code is, of course, a matter of personal opinion, but it is generally conceded that it should be such as to be easily carried in a coat pocket. The size, approximately 5 by 7 or $71 / 2$ inches, has been adopted by a number of cities and has proven to be very convenient. Such a size is recommended by this committee. Thickness of the book would vary with the completeness of the ordinance, but it would be a convenience to architects and others who have to use many codes if they could all be published in the same size.

The question of the size of type is also of vital importance for comfortable use of a building code. Ten-point leaded body type for linotype or monotype work, with the same size bold-face type for section headings and numbers is recommended. Liberal cross references are a distinct convenience in using a code, and such cross references are recommended to be printed in italics or other distinctive type. The reports of this committee are printed in 10point leaded body type and it will be seen that the text is easy to read. Chapter or article headings should be printed in larger type of distinctive character. If reference notes are necessary, they should not be printed in type smaller than 8 point. 


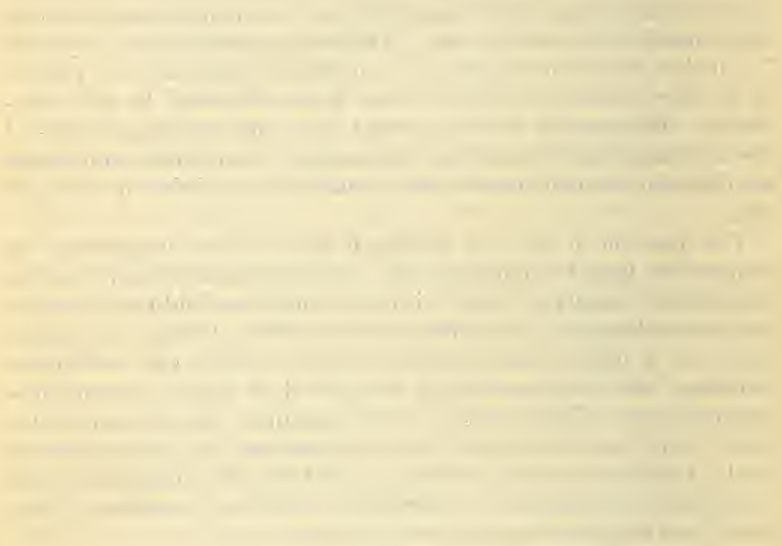





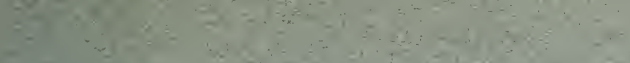

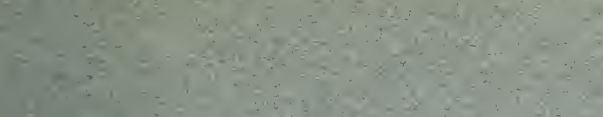

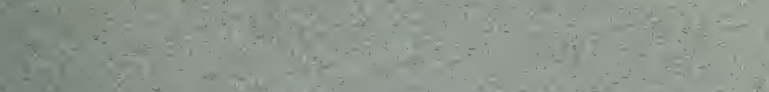

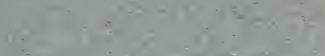

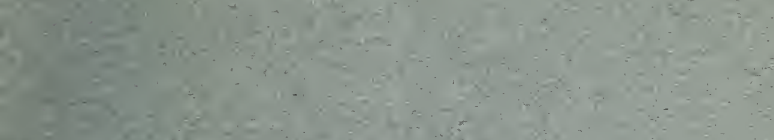

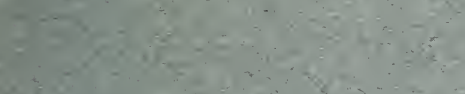
S. $x$

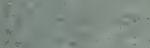

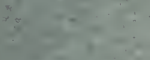

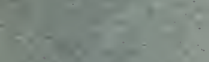

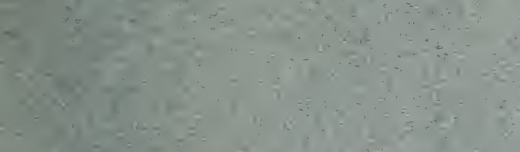

$\rightarrow$

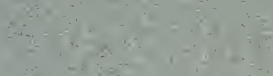

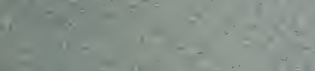

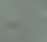

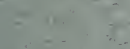

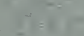

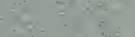

$\therefore-$

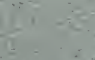

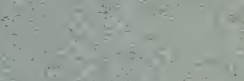

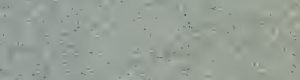

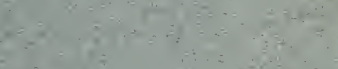

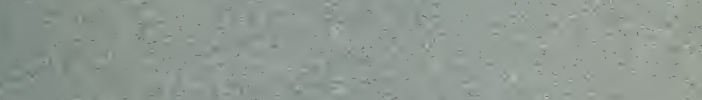

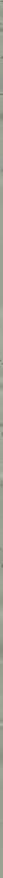

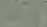
16. $9,10=$

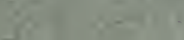




\title{
DEPARTMENT OF COMMERCE
}

\author{
WASHINGTON \\ PUBLICATIONS IN RELATION TO ROUSING AND MUNICIPAL \\ REGUI,ATION
}

(These publications may be obtained from the Superintendent of Documents, Government. Printing Office, Washington, D. C., payments to be made by money order or New York drait; eurrency at sender's risk. Postage stamps or forelgn money not aecepted.]

BH1. Recommended Minimum Requirements for Small Dwelling ConsTruCtion.

By the Building Code Committee: Ira H. Woolson, Chairman; Edwin H. Brown, William K. Hatt, Rudolph P. Miller, J. A. Newlin, Ernest J. Russell, and Joseph R. Worcester. 30 illustrations. 108 pages. Government Printing Office, Washington. Price, 15 cents.

BH2. Recommended Minimum Requirements for Plumbing in Dwellings And Simmar Buildings.

By the Subcommittee on Plumbing: George C. Whipple, Chairman; Harry Y, Carson, William C. Groeniger, Thomas F. Hanley, and A. E. Hansen. 100 illustrations. 250 pages. Government Printing Office, Washington. Price, 35 cents.

BH3. A Zoning Primer.

By the Advisory Committee on Zoning: Edward M. Bassett, Irving B. Hiett, John Ihlder, Morris Knowles, Nelson P. Lewis, J. Horace McFarland, Frederick Law Olmsted, and Lawrence Veiller. 12 pages. Government Printing Office, Washington. Price, 5 cents.

BH4. How to OwN Your Home.

By John M. Gries and James S. Taylor, with a foreword by Herbert Hoover, viii plus 28 pages. Government Printing Office, Washington, - Price, 5 cents.

BH5. A Standard State Zoning Enabling ACr.

By the Advisory Committee on Zoning. 12 pages. Government Printing Office, Washington: Price, 5 cents.

BH6. Recommended Minimum Reguirements for Másonry Wall ConstrucTION.

By the Building Code Committee. 57 pages. Government Printing Office, Washington. Price, 15 cents.

BH7. Minimum Live Lóns Allowable for Use in Design or Buildings.

By the Building Code Committee. 38 pages. Government Printing Office, Washington. Price, 10 cents.

Seasonal Operation in the Construction Industries.

Summary of Report and Recommendations of a Committee of the President's Conference on Unemployment, with a foreword by Herbert Hoover: viii plus 24 pages Government Printing Office, Washington. Price, 5 cents. [Department of Commerce Publication.] 





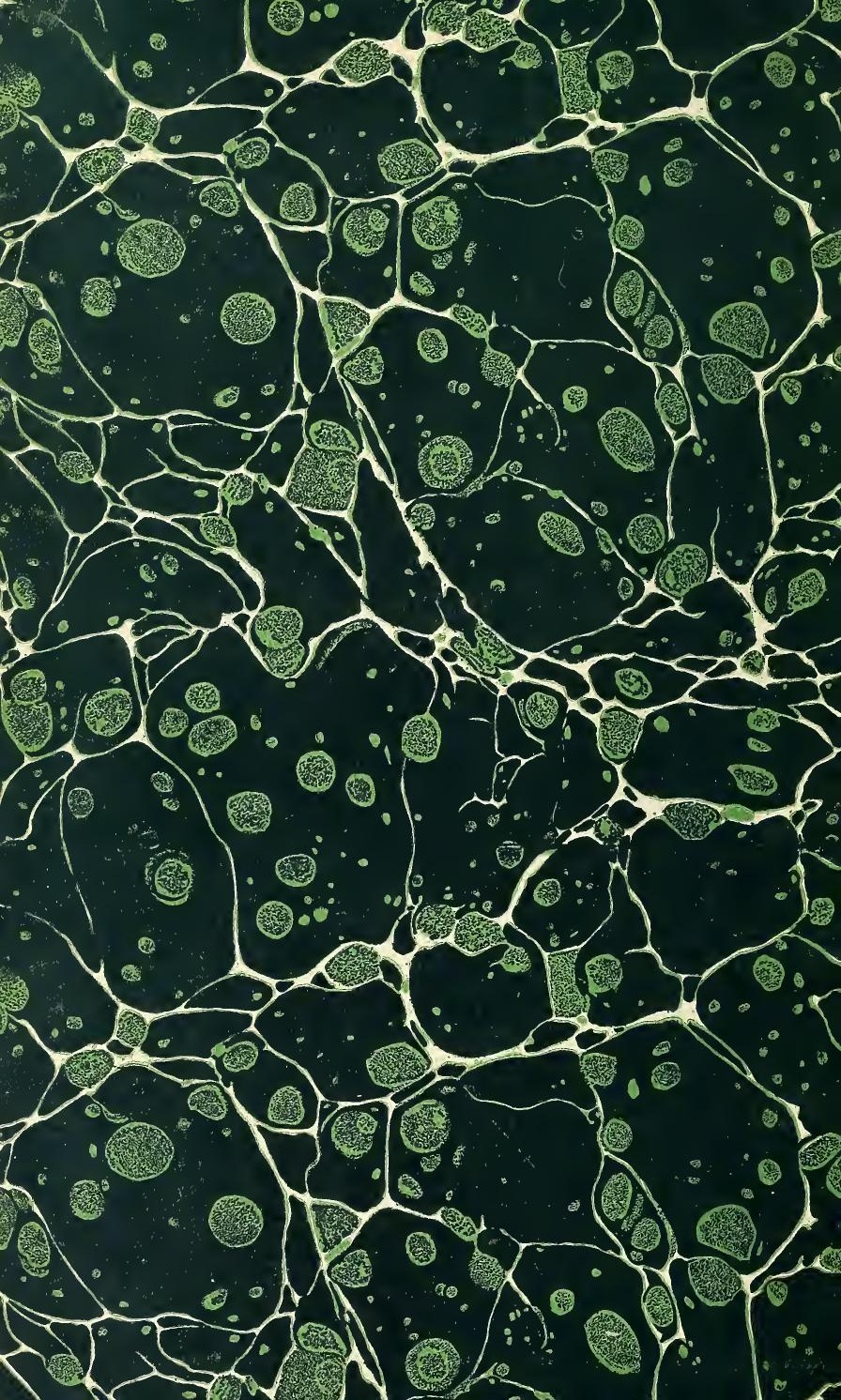





